\title{
POTENSI TAHAPAN STRATEGI PQ4R DIKOMBINASIKAN PETA KONSEP PADA PEMBELAJARAN BIOLOGI UNTUK MENINGKATKAN KETERAMPILAN METAKOGNITIF DAN BERPIKIR KRITIS SISWA
}

\author{
Siti Ramdiah \\ STKIP-PGRI Banjarmasin, Jl. Sultan Adam Komp. \\ H. Iyus No.18 Rt. 23 Banjarmasin \\ E-mail: sitiramdiah@gmail.com
}

\begin{abstract}
ABSTRAK
Proses pembelajaran yang menunjukkan ke arah teaching of thinking belum maksimal dilaksanakan bagi sebagian guru-guru di Indonesia. Berdasarkan berbagai hasil kajian diperoleh informasi bahwa keadaan tersebut sangat memprihatinkan, padahal keterampilan berpikir tersebut sangat penting untuk kehidupan pada abad 21 ini, sebagai kecakapan hidup siswa untuk mengatasi permasalahan kehidupan yang semakin kompleks. Oleh sebab itu, pemberdayaan keterampilan berpikir dapat dilakukan dengan latihan-latihan berpikir. Tulisan ini merupakan salah satu solusi dalam mengatasi permasalahan tersebut, dengan menerapkan strategi pembelajaran $\mathrm{PQ} 4 \mathrm{R}$ dikombinasikan peta konsep untuk meningkatkan keterampilan metakognitif dan berpikir kritis siswa. Strategi pembelajaran PQ4R dikombinasikan peta konsep memiliki 7 tahapan yang memiliki karakteristik proses pengulangan informasi dan pengkodean konsep dalam struktur kognitif sehingga siswa memperoleh pembelajaran yang bermakna.
\end{abstract}

Kata Kunci: PQ4R, peta konsep, keterampilan metakognitif, berpikir kritis

Permasalahan hasil belajar siswa yang rendah sebagian besar disebabkan oleh proses pembelajaran yang belum maksimal dilaksanakan. Proses pembelajaran yang diberikan belum menunjukkan kearah teaching of thinking yaitu pembentukan keterampilan mental tertentu seperti keterampilan metakgnitif dan berpikir kritis siswa. Hal tersebut karena rancangan yang telah dibuat oleh guru belum memfasilitasi siswa dalam memberdayakan keterampilan metakognitif dan berpikir kritis. Fakta tersebut di lapangan guru lebih menekankan pada penghapalan konsep dan teaching directed, sehingga siswa kesulitan dalam memahami secara mendalam konsep yang diberikan. Berdasarkan kajian yang telah dilakukan oleh Sastrawati, ddk. (2011), Nurmaliah (2009), Warouw (2010), Risnanosanti (2008), Paidi (2009), Suratno (2009), Juhrian (2012), Lukitasari (2014), dan Ramdiah (2014) fenomena di Indonesia saat ini menunjukkan bahwa pemberdayaan keterampilan metakognitif dan berpikir kritis belum dilakukan dengan maksimal.

Kendala-kendala yang sering muncul seperti dominannya peran guru, sehingga siswa hanya sebagai tempat yang akan diisi dengan ilmu dan sistem penilaian prestasi siswa yang lebih banyak pada pengujian kemampuan kognitif tingkat rendah dan bentuk penilaian yang dilakukan berupa soalsoal pilihan ganda yang banyak memerlukan kemampuan siswa untuk 
menghafal (Sastrawati, dkk. 2011, Ramdiah, 2014). Lebih lanjut dijelaskan oleh Nurmaliah (2009) menunjukkan bahwa keterampilan berpikir dan keterampilan metakognitif siswa kurang atau bahkan tidak diberdayakan secara sengaja selama proses pembelajaran, penyebabnya yaitu kesibukan guru untuk memacu perolehan nilai ujian yang baik melalui teknik ceramah, tryout, dan lain sebagainya. Berdasarkan hasil survei Warouw (2010) menunjukkan bahwa guru-guru belum mengetahui tentang apa dan bagaimana pembelajaran dengan memberdayakan keterampilan metakognitif Ditambahkan oleh Risnanosanti (2008) aspek kemampuan metakognisi sebagai syarat penguasaan pemecahan masalah belum banyak disentuh oleh para guru. Selanjutnya Paidi (2009) melalui penelitiannya mengemukakan bahwa indikator rendahnya pembelajaran biologi yaitu rendahnya kemampuan berpikir siswa.

Berdasarkan fakta yang telah diuraikan tersebut maka diperlukan kegiatan pembelajaran dengan rancangan yang dapat memberdayakan keterampilan metakognitif dan berpikir kritis sehingga siswa mampu membangun sendiri konsep dan pemahaman yang mendalam pada konsep yang diberikan. Strategi pembelajaran yang dirancang secara terencana dengan baik akan menuntun siswa dalam mengembangkan keterampilan metakognitif dan berpikir kritis yang melatihkan siswa untuk menjadi lebih berkemampuan dalam menghadapi permasalahan, memiliki rasa percaya (confidence) dan menjadi lebih independen sebagai pebelajar. Selanjutnya, seseorang yang memiliki kemampuan berpikir kritis dapat mengajukan pertanyaan-pertanyaan, mengumpulkan informasi yang relevan, secara efisien dan kreatif menyusun dan berbuat melalui informasi yang dikumpulkan tersebut, bernalar secara logika atas dasar informasi yang didapat, dan memiliki kesimpulan yang reliabel serta dapat dipercaya (Schafersman, 1991). Menurut Kadir (2009) beberapa siswa dengan proses refleksi diri berhasil menemukan pengetahuan tentang kemampuannya, sehingga dapat mengontrol dirinya sendiri untuk mengulang pelajaran. Arends (2004) menyatakan metakognitif sebagai berpikir tentang berpikir dan pemonitoran proses kognitif. Ditambahkan oleh Hanten, dkk. (2004) keterampilan metakognitif merupakan kegiatan merefleksikan proses mental individu sebagai karakteristik unik terkait dengan proses kognitifnya dan dapat di ketahui melalui kegiatan perencanaan, monitoring dan evaluasi. Senada dengan hal tersebut Lee dan Baylor (2006) ada empat komponen keterampilan metakognitif yaitu 1). Planning merupakan aktivitas yang dilakukan secara hati-hati yang mengatur seluruh proses belajar. Perilaku merencanakan terdiri atas menetapkan tujuan belajar, urut-urutan belajar, strategi-strategi belajar dan harapan saat belajar. 2). Monitoring menunjukkan pada aktivitas yang moderat pada kemajuan belajar, merupakan pemantauan selama aktivitas belajar, sebagai contoh yaitu bertanya pada diri sendiri. 3). Evaluating 
merupakan evaluasi proses belajar diri sendiri meliputi asesmen kemajuan aktivitas belajar. Metode sistematis evaluating dapat membantu dalam mengembangkan set keterampilan dan strategi-strategi. 4). Revising merupakan merevisi proses belajar diri sendiri yang meliputi modifikasi rencana tujuan sebelumnya, strategi-strategi, dan pendekatan belajar lainnya.

Hal tersebut menunjukkan bahwa hasil belajar memiliki keterkaitan dengan keterampilan metakognitif. Siswa memiliki kemampuan dalam memonitor dan mengontrol proses pembelajarannya dengan baik dan mengimplementasikan keterampilan metakognitif dan berpikir kritis pada banyak proses termasuk dalam pembelajaran biologi. Perkembangan keilmuan biologi sebagai metode berpikir ilmiah saat ini menempatkan biologi pada posisi strategis dalam memberdayakan keterampilan metakognitif siswa. Pada bidang penelitian perkembangan keilmuan biologi memiliki prospek untuk terus berkembang. Oleh sebab itu para pendidik bidang biologi diharapkan mampu membelajarkannya sesuai dengan perkembangan keilmuan biologi sekarang (learn how to learn biology).

Pada uraian di atas jika dikaitkan dengan tahapan strategi pembelajaran PQ4R yang dikombinasikan dengan peta konsep memiliki potensi dalam mengembangkan keterampilan metakognitif dan berpikir kritis siswa. Tahapan strategi pembelajaran PQ4R mengikuti tahapan proses berpikir siswa, dimana dalam pelaksanaannya siswa berpikir dan menjawab pertanyaan yang dibuat oleh siswa sendiri dari materi yang dibaca, hal ini menunjukkan suatu proses pengulangan informasi. Selanjutnya, pada strategi pembelajaran peta konsep membiasakan siswa untuk mengidentifikasi konsep atau ide-ide pokok yang telah diketahui maupun yang belum diketahuinya. Penyusun konsep tersebut sesuai dengan pola peta pikiran siswa terhadap suatu materi yang dibacanya. Selain itu untuk peta konsep dapat membantu mengingat informasi lebih lama dan lebih efektif. Hal ini akan sangat membantu siswa memproses informasi dan kerja mental ini penting pada saat siswa mempelajari materi baru yang sulit. Menurut Ramdiah (2014) berdasarkan hasil penelitian terkait strategi pembelajaran PQ4R dikombinasikan dengan peta konsep telah terbukti memiliki potensi yang besar untuk meningkatkan keterampilan metakognitif, kemampuan berpikir kritis, hingga memberikan efek positif dalam meningkatkan hasil belajar kognitif biologi serta mampu mempertahankan retensi siswa putra maupun putri kelas XI IPA SMA di kota Banjarmasin. Namun, tidak menutup kemungkinan strategi pembelajaran ini juga dapat digunakan pada tingkat pendidikan yang lain seperti perguruan tinggi yang juga memperhatikan gender maupun akademik yang berbeda.

\section{Tahapan Strategi Pembelajaran PQ4R Dikombinasikan Peta Konsep}

Strategi pembelajaran PQ4R dikombinasikan peta konsep memiliki 
karakteristik yaitu proses pengulangan informasi dan pengkodean konsep dalam struktur kognitif siswa sehingga siswa memperoleh pembelajaran yang bermakna. Karakteristik tersebut akan membantu siswa dalam mengembangkan keterampilan metakognitif dan berpikir kritisnya. Langkah-langkah dalam kombinasi kedua strategi ini melibatkan kegiatan seperti membaca (membaca sekilas, membaca keseluruhan, dan mengkaji ulang), atensi/perhatian (kegiatan identifikasi ide-ide pokok). Selanjutnya pengkodean (melalui kegiatan menghubungkan ide-ide pokok tersebut dengan garis dan kata-kata penghubung bahkan bentuk kotak yang dibuat pada peta konsep). Berikut akan diuraikan tahapan strategi pembelajaran PQ4R dikombinasikan peta konsep.

\section{Tahap 1. Preview (peninjauan)}

Tahap 1 mengacu kepada memperoleh informasi awal yang diperlukan untuk menentukan tujuantujuan dan berkonsentrasi pada teks. Pada tahap ini, siswa dapat membaca judul, subjudul, dan gambar-gambar atau grafik-grafik. kemudian untuk meninjau materi atau bahan bacaan, siswa-siswa perlu untuk meninjau teks dengan cepat dan memahami pointpoint utama dan bagaimana informasi ini disusun.

\section{Tahap 2. Question (Membuat pertanyaan)}

Tahap pertanyaan (Question) ini dapat membantu untuk fokus pada bagian bacaan dengan membuat sebanyak mungkin pertanyaan mengenai bahan bacaan yang diberikan. Selain itu dengan pertanyaanpertanyaan mendapatkan kesempatan untuk merencanakan atau identifikasi informasi penting yang diperoleh dari membaca. Pada tahap ini siswa-siswa membuat pertanyaan-pertanyaan berdasarkan pada survei yang telah mereka lakukan sebelumnya. Pertanyaan-pertanyaan dasar dimulai dengan kata-kata seperti apa (what), mengapa (why) atau bagaimana (how). Selanjutnya, pertanyaan-pertanyaan yang spesifik dimulai dengan kata-kata kapan (when), dimana (where) atau siapa (who). Siswa juga dapat merubah judul-judul dalam bab menjadi pertanyaan-pertanyaan.

\section{Tahap 3. Read (membaca) dan memulai merangkai peta konsep}

Proses membaca (read) merupakan sebuah proses berfikir, setelah mengutarakan pertanyaanpertanyaan pada materi bacaan tersebut siswa dapat menjawab pertanyaanpertanyaannya. Siswa akan mengalami proses berpikir, memprediksikan, mempertanyakan, dan mengevaluasi dalam aktifitas membaca.

Tahap 4. Reflect (Refleksi) dan menghubungkan antar konsep satu dengan garis dan kata penghubung

Refleksi (reflect) adalah berpikir mengenai isi pokok (substance) yang baru saja dibaca, menghubungkan dengan informasi yang baru ke hal-hal 
yang sudah ada dalam pengetahuan seperti ide-ide atau gagasan-gagasan dari apa yang sudah diketahui. Pada tahap ini guru harus memberikan waktu yang cukup lama kepada siswa-siswa untuk merefleksikan bacaan mereka sendiri. Refleksi merupakan proses berpikir yang melibatkan: menghubungkan informasi baru ke informasi yang lama, menghubungkan informasi baru dengan peristiwaperistiwa dalam kehidupan pribadi siswa, menghubungkan informasi baru dengan yang lama, membandingkan dan membedakan fakta-fakta, menghubungkan informasi dengan fakta-fakta serupa yang lainnya, konsep-konsep dan prinsip-prinsip.

Pada tahap ini karakteristik peta konsep dilakukan melalui kegiatan menghubungkan konsep dengan menggunakan garis dan kata penghubung yang benar pada setiap keterkaitan antar konsep, selanjutnya siswa juga menentukan mana konsep yang umum dan konsep yang khusus pada bahan bacaan tersebut, agar konsep tersebut jelas dalam sebuah peta konsep.

\section{Tahap 5. Recite (menceritakan kembali) dan mengungkapkan kembali isi peta konsep}

Recite yaitu menceritakan kembali yang meliputi pengulangan informasi. Pada tahapan ini siswa dapat menjawab pertanyaan-pertanyaan melalui menceritakan kembali bahan atau materi tersebut ke diri sendiri, baca ulang pertanyaannya bila perlu. Selanjutnya, lihatlah pada definisi- definisi dan contoh-contohnya dan tinjaulah bagian-bagian sebelumnya dan pastikan siswa dapat menceritakan kembali semua bahan atau materi tersebut. Pada tahap ini siswa juga diharapkan mampu mengingat hubungan antar konsep dan bentuk peta konsep yang dibuat serta kata yang digunakan sebagai kata penghubung antar konsep.

\section{Tahap 6. Review (meresensi)}

Tahap meresensi (review) yaitu dimana siswa harus meresensi bacaan untuk menyimpan apa yang sudah dibaca, hal ini dilakukan mengingat kecenderungan seseorang melupakan sebagian besar informasi yang tersimpan di memori kita. Pada tahap ini guru dapat mengarahkan siswa secara individu maupun kelompok untuk melakukan beberapa kegiatan berikut, seperti: a) membaca ulang bahan bacaan yang diberikan, b) kembali menjawab pertanyaanpertanyaan yang diprediksi selama langkah pertanyaan (question), c) mendata point-point kunci dari teks tersebut, secara lisan maupun secara tulisan, d) mengulang tahapan pertama dengan hanya membaca bagian-bagian yang dipilih dari bacaan tersebut, e) menyusun pertanyaan-pertanyaan tambahan kepada diri sendiri jika memang diperlukan, f). menjelaskan apa yang sudah dibaca ke teman, g) membuat sebuah ringkasan, tanpa melihat catatan, ceritakanlah kembali ringkasan dari memori, serta secara individu baca lagi teks tersebut untuk memantau keyakinan dan untuk 
mengidentifikasi aspek-aspek yang diperlukan untuk pengembangan selanjutnya.

\section{Tahap 7. Presentasi}

Pada tahap ini siswa secara berkelompok berdiskusi untuk mencek ulang peta konsep yang telah dibuat dan menyepakati salah satu peta konsep untuk dipresentasikan. Selanjutnya, salah satu siswa mempresentasikan peta konsep yang telah dibuat di depan kelas. Aktivitas guru dan siswa pada strategi pembelajaran PQ4R dikombinasikan peta konsep dapat dilihat pada Tabel 1 .

\section{Tabel 1. Tahapan-Tahapan Strategi Pembelajaran PQ4R Dikombinasikan Peta Konsep}

\begin{tabular}{|c|c|c|}
\hline Tahapan & Aktivitas Guru & Aktivitas Siswa \\
\hline Tahap 1 & $\begin{array}{l}\text { a. Memberikan bahan bacaan kepada siswa untuk } \\
\text { dibaca selintas } \\
\text { b. Menginformasikan kepada siswa bagaimana menemukan } \\
\text { ide pokok yang melingkupi sejumlah konsep. }\end{array}$ & $\begin{array}{l}\text { Membaca selintas bahan bacaan yang } \\
\text { telah diberikan untuk menemukan ide } \\
\text { pokok bahan bacaan. }\end{array}$ \\
\hline Tahap 2 & $\begin{array}{l}\text { a. Menginformasikan kepada siswa agar mengidentifikasi } \\
\text { ide-ide pokok bahan bacaan. } \\
\text { b. Memberikan tugas kepada siswa untuk membuat } \\
\text { pertanyaan dari ide pokok yang ditemukan dengan } \\
\text { menggunakan kata-kata apa, mengapa, siapa, dan } \\
\text { bagaimana. }\end{array}$ & $\begin{array}{l}\text { a. Memperhatikan penjelasan guru } \\
\text { b. Mengidentifikasi ide-ide pokok dari } \\
\text { bahan bacaan } \\
\text { c. Membuat pertanyaan dari ide pokok } \\
\text { yang ditemukan dengan } \\
\text { menggunakan kata apa, mengapa, } \\
\text { siapa, dan bagaimana. }\end{array}$ \\
\hline
\end{tabular}

Tahap 3 Memberikan tugas kepada siswa untuk membaca lebih seksama sekaligus menemukan jawaban atas pertanyaan pada langkah 2 dan siswa memulai untuk membuat peta konsep dengan menentukan urutan-urutan topik/konsep dari umum ke khusus.
Membaca lebih seksama sekaligus menemukan jawaban atas pertanyaan pada tahap 2 dan memulai untuk membuat peta konsep dengan menemukan urutan-urutan topik/konsep dari umum ke khusus.
Tahap 4 Memberikan tugas kepada siswa untuk menghubungkan dan mengaitkan antar konsep dengan membuat garis-garis dan kata penghubung antar topik/konsep dari umum ke khusus.
Menghubungkan dan mengaitkan antar konsep dengan membuat garis-garis dan kata penghubung antar topik/konsep dari umum ke khusus. $\begin{array}{ll}\text { Tahap 5 } & \text { Menginformasikan kepada siswa untuk } \\ & \text { merenung/mengingat kembali isi peta konsep yang telah } \\ & \text { dibuat melalui pertanyaan dan jawaban di atas. Sehingga } \\ & \text { seluruh topik sudah terangkum dalam peta konsep tersebut. }\end{array}$

Tahap 6 Mengkomunikasikan kepada siswa dalam kelompok agar mendiskusikan dan mencek ulang peta konsep yang telah dibuat secara individu dan menyepakati satu peta konsep yang terbaik untuk mempresentasikan di depan kelas.
Merenung/mengingat kembali isi peta konsep yang telah di buat melalui pertanyaan dan jawaban di atas (diharapkan pemahaman siswa meningkat pada langkah ini).
Tahap 7 Menginformasikan kepada siswa untuk mempresentasikan peta konsep yang telah disepakati oleh kelompok.
Mendiskusikan dan mencek ulang peta konsep yang telah dibuat secara individu dan menyepakati satu peta konsep yang terbaik untuk mempresentasikan di kelas. 


\section{Potensi Tahapan Strategi Pembelajaran PQ4R Dikombinasikan Peta Konsep pada Pembelajaran Biologi untuk Meningkatkan Keterampilan Metakognitif dan Berpikir Kritis Siswa}

Berdasarkan uraian tahapan kegiatan dalam strategi pembelajaran PQ4R dikombinasikan peta konsep jika dianalisis secara mendalam masingmasing tahapannya berpotensi dalam upaya meningkatkan keterampilan metakognitif dan kemampuan berpikir kritis siswa.

Kegiatan pembelajaran pada tahap 1 (Preview) membaca sekilas bahan bacaan yang diberikan, hal ini dapat dilakukan untuk melihat struktur secara keseluruhan (menyurvei), agar ide pokok dapat dikutip. Menurut Bibi (2011) preview merupakan bagian awal yang dilakukan untuk meninjau teks dengan cepat dan memahami pointpoint utama.

Tahap 2 (Question) atau membuat pertanyaan atas bahan bacaan dengan kata-kata apa, siapa, dimana, kapan, mengapa dan bagaimana atau 5W1H (What, Who, Where, When, Why, dan How). Lebih lanjut, Bibi (2011) dan Fisher (1998) pertanyaan (Question) dapat membantu untuk fokus pada bagian bacaan dan membuat pertanyaan-pertanyaan memberikan kesempatan untuk merencanakan atau identifikasi informasi penting yang diperoleh dari membaca, sehingga mampu memperluas keingintahuan siswa. Selain itu dengan merubah juduljudul dalam bab menjadi pertanyaanpertanyaan, akan memberikan wawasan dalam pengaturan materi pelajaran dan hubungan antar ide-ide dan belajar menjadi sebuah proses yang aktif. Ditambahkan oleh D'avanzo (2003) menyatakan bahwa pencapaian tertinggi dalam berpikir adalah ketika siswa mampu bertanya dan menjawab pertanyaan sendiri. Senada dengan hal tersebut, Jacobsen, dkk. (2009) menjelaskan bahwa hal ini dapat membantu siswa memperbaiki konten dan mengajari siswa berpikir lebih kritis dan analitis. Pertanyaan-pertanyaan tingkat tinggi (high level question). mengharuskan siswa untuk menerapkan, menganalisis, dan mengevaluasi informasi adalah tujuan utama dalam mendorong kemampuan-kemampuan berpikir tingkat tinggi.

Tahap 3 (Read) membaca kembali untuk menemukan jawaban, sekaligus siswa merangkai peta konsep berdasarkan bahan bacaan yang diberikan. Kegiatan ini menuntut siswa untuk merangkai konsep sehingga memiliki hubungan yang bermakna antar konsep. Hal ini dilakukan agar siswa dapat memahami apa yang mereka baca dan menambah pengetahuan yang sudah mereka ketahui. Lebih lanjut dijelaskan, langkah membaca (read) dari PQ4R mendorong untuk membaca dengan hati-hati. Membaca paragrap demi paragrap dari buku teks untuk berkonsentrasi dan memahami satu bagian dari informasi pada waktu yang sama. Membaca dengan hati-hati dapat menghemat dari membaca ulang (reread). Membaca sekaligus menemukan jawaban-jawaban dari pertanyaan-pertanyaan yang diajukan 
dapat membantu fokus pada point-point kunci pada materi (Bibi, 2011). Selanjutnya pada tahap ini siswa memulai merangkai peta konsep dengan tujuan agar konsep-konsep yang telah ditemukan pada tahapan sebelumnya berada pada hirarki yang benar sehingga siswa memperoleh pembelajaran yang bermakna. Lebih lanjut Novak, (2008). menjelaskan bahwa pembelajaran bermakna membutuhkan kondis dimana bahan yang dipelajari harus konseptual dan disajikan dengan bahasa yang jelas. Peta konsep dapat membantu untuk memenuhi kondisi ini, baik dengan mengidentifikasi konsep-konsep umum yang besar sebelum instruksi dalam konsep yang lebih spesifik. Ditambahkan oleh Halpern \& Milton (2003) belajar dan mengingat dapat ditingkatkan ketika siswa mengintegrasikan informasi dari presentasi baik verbal dan visuospatial, seperti peta konsep. Menurut Ching (2004) peta konsep sebagai alat untuk mengukur pemahaman siswa dan mengidentifikasi setiap miskonsepsi dalam hubungan antara konsep-konsep. Peta konsep lebih cocok untuk memberdayakan hasil belajar kognitif yakni sampai pada dimensi analisis (Tindangen, 2006).

Tahap 4 (Reflect)

menghubungkan dan mengkaitkan jawaban dan pertanyaan yang telah dirangkai pada peta konsep. Dijelaskan lebih lanjut bahwa siswa dapat belajar secara efektif ketika siswa merefleksikan pada apa yang siswa pelajari. Merefleksikan berarti menghubungkan dengan hal-hal yang sudah siswa ketahui. Proses ini membuat materi tersebut berarti dan dapat diingat, dan siswa mampu mengaplikasikan informasi ke kehidupannya. Tahap refleksi dari strategi pembelajaran PQ4R dikombinasikan peta konsep ini membantu untuk mendapatkan kembali informasi sebelumnya yang tersimpan dalam memori jangka panjang, menolak atau menerima informasi baru, kemudian merekonstruksinya, lalu menyatakannya lagi dalam memori jangka panjang untuk penggunaan berikutnya.

Tahap 5 (Recite) atau menceritakan kembali untuk mengingat informasi yang diperoleh terkait bahan yang diberikan, pertanyaan, jawaban yang telah dirangkai pada peta konsep. Tahap ini membantu siswa memahami lebih mendalam tentang bahan bacaan. Pada tahapan ini merupakan proses pengulangan informasi untuk kedua kalinya setelah membaca (read). Hal tersebut senada dengan yang dikemukakan oleh Slavin (2008) pengulangan mental berperan penting dalam menempatkan informasi baru ke dalam daya ingat jangka panjang. Informasi yang diterima dalam daya ingat kerja harus diulangi dalam pikiran kalau informasi tersebut ingin disimpan selama lebih daripada beberapa detik.

Tahap 6 (Review) atau meresensi merupakan kegiatan mengulang kembali jika ada yang belum dipahami, hingga membuat ringkasan dengan baik. Tahap ini penting menurut Eggen \& Kauchak (2012) yang agar proses pembelajaran menjadi bermakna. Menurut Bibi (2011) meresensi (review) merupakan sebuah unsur yang penting 
dalam proses tersebut, karena bertujuan untuk mengembangkan kesadaran metakognitif pada proses tersebut, isi dan respons setiap individu. Hal ini bertujuan untuk membantu siswa mengidentifikasi apa yang sudah mereka pelajari dari pengalamannya dimana mereka dan yang lain-lainnya telah mencapai kesuksesan, dan caracara mereka atau kelompok untuk memperbaikinya di masa mendatang. Dengan demikian tahap ini bagi siswa dapat memantau keyakinan dan mengidentifikasi aspek-aspek yang diperlukan dalam pengembangan pengetahuan selanjutnya.

Tahap 7 atau Presentasi merupakan tahap akhir strategi pembelajaran PQ4R dikombinasikan peta konsep. Pada tahap ini siswa yang telah berkelompok sejak awal kegiatan strategi pembelajaran ini melakukan diskusi untuk menemukan kesepakatan atas peta konsep yang akan dipresentasikan. Hal ini juga memberikan sumbangan atas pemberdayaan keterampilan metakognitif dan kemampuan berpikir kritis, serta pendalaman materi hingga mempertahankan retensi siswa. Siswa dilatih untuk bekerjasama dan saling bertukar pendapat dalam kelompok Hal ini mengungkapkan bahwa kesadaran siswa dalam pentingnya belajar dan saling membelajarkan sehingga dapat terbentuk keterampilan metakognitif dalam diri siswa. Terkait dengan peningkatan hasil belajar kognitif siswa dilatih untuk bekerjasama agar menjadi kelompok dengan hasil belajar yang terbaik dan saling bertukar pendapat dalam kelompok. Menurut Sudaryanto (2008) dengan berdiskusi siswa berkesempatan untuk mengklarifikasi pemahamannya dan mengevaluasi pemahaman siswa lain, mengobservasi strategi berpikir dari orang lain untuk dijadikan panutan, membantu siswa lain yang kurang untuk membangun pemahaman, meningkatkan motivasi, serta membentuk sikap yang diperlukan seperti menerima kritik dan menyampaikan kritik dengan cara yang santun. Ditambahkan oleh Jacobsen, dkk. (2009) bahwa keterampilanketerampilan berpikir kritis seperti mengidentifikasi dan menganalisis dapat ditingkatkan melalui diskusi kelompok.

Tabel 2. Ringkasan Potensi Strategi Pembelajaran PQ4R Dikombinasikan Peta Konsep

\begin{tabular}{cll}
\hline Tahapan & \multicolumn{1}{c}{ Kegiatan/Karakteristik } & \multicolumn{1}{c}{ Potensi } \\
\hline Tahap 1 & $\begin{array}{l}\text { Pengorganisasian konsep secara } \\
\text { umum }\end{array}$ & $\begin{array}{l}\text { Pemahaman konsep pada point-point } \\
\text { utama }\end{array}$ \\
\hline Tahap 2 & Pengajuan pertanyaan & $\begin{array}{l}\text { Memperluas keingintahuan dan } \\
\text { mengembangkan kemampuan berpikir } \\
\text { tingkat tinggi }\end{array}$ \\
\hline Tahap 3 & $\begin{array}{l}\text { Pengklasifikasian konsep dan } \\
\text { Pemprosessan informasi (Proses } \\
\text { pengulangan) }\end{array}$ & $\begin{array}{l}\text { Memahami lebih mendalam tentang } \\
\text { bahan bacaan dengan menciptakan } \\
\text { kerangka organisasi }\end{array}$ \\
\end{tabular}




\begin{tabular}{ll}
\hline Tahap 4 & $\begin{array}{l}\text { Mengidentifikasi berbagai jenis } \\
\text { hubungan antar konsep dengan } \\
\text { proses pengkodean. }\end{array}$
\end{tabular}

Tahap 5 Mempertimbangkan dan merumuskan konsep (Proses pengulangan)
Memiliki kemampuan untuk mengorganisir dan mengatur belajar nya sendiri.

Meningkatkan pemikiran reflektif tentang apa yang telah diketahui.

Membimbing pengembangan keyakinan dan pengambilan keputusan/tindakan

Tahap 6 Membuat ringkasan dan memeriksa Mengembangkan kesadaran metakognitif dan 7 keakuratan belajar

\section{KESIMPULAN}

Artikel konseptual ini menyampaikan bahwa salah satu cara mengatasi permasalahan dalam meningkatkan keterampilan metakognitif dan berpikir kritis siswa dapat dengan menggunakan strategi pembelajaran PQ4R dikombinasikan peta konsep. Strategi pembelajaran ini terdiri atas 7 tahapan dan memberikan kontribusi terhadap pemberdayaan keterampilan metakognitif dan berpikir kritis, sehingga akan berdampak pada hasil belajar bahkan retensi siswa.

\section{DAFTAR PUSTAKA}

Arends, R. 2008. Learning to Teach. ( $7^{\text {th }}$ edition). New York: Mc Grow Hill.

Bibi, R. 2011. Effect of PQ4R Study Strategy in Scholostic Achievement of Secondary School Student in Punjab (Pakistan). Submitted In Partial Fulfillment Of The Requirements For The Degree Of Doctor Of Philosophy In Education Foundation University Islamabad, Pakistan, (Online), (eprints.hec.gov.pk), diakses 15 Deseember 2013.

Ching. 2004. Using Concept Maps to Gauge Students' Understanding. The Internet TESL Journal, Vol.
X, No. 3, (Online), (http://iteslj.org/Techniques/Lee_ ConceptMaps), diakses 1 September 2012.

D’Avanzo, C. 2003. Research on Learning: Potential for Improving College Ecological Examples. Bioscience. 1(10): 533-540, (Online), (www.frontiersinecology.org), diakses 5 Oktober 2013.

Eggen, P. \& Kauchak, D. 2012. Strategi dan Model Pembelajaran. Mengajarkan Konten dan Keterampilan Berpikir. Terjemahan oleh Satrio Wahono. Jakarta: Indeks.

Fisher, R. 1998. Teaching Thinking and Creativity Developing Creative Minds and Creative Futures Thinking about Thinking: Developing Metacognition in Children. This paper was first published in Early Child Development and Care Vol 141 (1998) pp1-15, (Online), (http://www.teachingthinking.net), diakses 20 Desember 2013.

Halpern, D.F. \& Milton, D.H. 2003. Teaching for Long Term Retention and Transfer. Applying the Science of Learning to the 
University and Beyond: Cognitive, Motivational, and Social Factors, (Online), (at berger.

claremontmckenna.edu/asl), diakses 18 Desember 2013.

Hanten, G., Dennis, M., Zhang, L., Barnes, M.,Roberson, G., Archibald, J.,Song, J., \& Levin, H.S. 2004. Childhood Head Injury and Metacognitive Processes in Language and Memory. Development Neuropsychology, 25 (1 \& 2); 85-105.

Jacobsen, D.A., Enggen, P. \& Kauchak, D. 2009. Methode for Teaching. Metode-Metode Pengajaran Meningkatkan Belajar Siswa TKSMA. Terjemahan oleh Achmad Fawaid dan Khoirul Anam. Yogyakarta: Pustaka Pelajar.

Juhrian. 2012. Keterampilan Berpikir dan Hasil Belajar Melalui Penerapan Perangkat Pembelajaran Model Kooperatif Tipe STAD dengan Pendekatan Lingkungan Konsep Keanekaragam Hayati di SMA Islam Sabilal Muhtadin Banjarmasin, (Online), (http://propil-sains.blogspot.com), diakses 23 Agustus 2013.

Kadir. 2009. Meningkatkan Metakognisi Siswa dalam Pembelajaran Matematika Melalui Asesmen Kinerja Berbasis Masalah dan Model Pembelajaran, (Online), (anniselvy.files.wordpress.com/20 12/06/metakognisi-asli2.pdf), diakses 23 Agustus 2013.

Lee, M. \& Baylor, A.L. 2006. Designing Metacognitive Maps for Web-Based Learning. Educational Technology \&Society, 9 (1), 344-348, (Online), (www.ifets.info/journals), diakses 23 Agustus 2013.

Lukitasari, M. 2014. Pengembangan Perangkat Pembelajaran Biologi Sel Berbasis Electronic Portofolio Didukung Lesson Study untuk Meningkatkan Kemampuan Metakognitif dan Pemahaman Konsep Mahasiswa. Disertasi tidak diterbitkan. Malang: PPs UM.

Novak, J. D. 2008. Concept Maps: What the heck is this? Excerpted, Rearranged (and Annotated). Cornell University, (Online), (http://cmap.ihmc.us), diakses 23 Desember 2013.

Nurmaliah, C. 2009. Keterampilan Berpikir Kritis, Metakognitif, dan Hasil Belajar Biologi Siswa SMPN di Kota Malang. Disertasi tidak diterbitkan. Malang: PPs UM.

Paidi. 2008. Pengembangan Perangkat Pembelajaran Biologi yang Mengimplementasikan PBL dan Strategi Metakognitif serta Efektifitasnya terhadap Kemampuan Metakognitif, Pemecahan Masalah dan Penguasaan Konsep Biologi Siswa SMA di Sleman Yogyakarta. Disertasi tidak diterbitkan. Malang: PPs UM.

Ramdiah, S. 2014. Pengaruh Strategi Pembelajaran PQ4R Diintegrasikan Peta Konsep dan Gender terhadap Keterampilan Metakognitif, Berpikir Kritis, Hasil Belajar Kognitif Biologi, 
dan Retensi Siswa SMA Di Kota Banjarmasin. Disertasi tidak diterbitkan. Malang: PPs UM.

Risnonosanti. 2008. Melatih Kemampuan Metakognisi Siswa dalam Pembelajaran Matematika. Makalah disajikan pada Seminar Nasional Matematika dan Pendidikan Matematika. Jurusan Pendidikan Matematika FKIP Universitas Muhammdiyah Bengkulu, (Online), (eprints.uny.ac.id), diakses 23 Agustus 2013.

Sastrawati, E., Muhammad, R. \& Syamsurizal. 2011. ProblemBased Learning, Strategi Metakognisi, dan Keterampilan Berpikir Tingkat Tinggi Siswa. Tekno-Pedagogi, 1 (2): 1-14 (Online), (http://Onlinejournal.unja.ac.id), diakses 23 Agustsus 2013.

Schafersman, S.D. (1991) An Introduction to Critical Thinking, (Online), (http://facultycenter.ischool.syr.ed u), diakses 23 Agustus 2013.

Slavin. 2008. Psikologi Pendidikan teori dan Praktek. Jilid 1. Jakarta: Indeks.

Sudaryanto. 2008. Kajian Kritis tentang PermasalahanSekitar

Pembelajaran Kemampuan Berpikir Kritis. Jakarta: Ilmu Pendidikan kedokteran Fakultas Kedokteran Universitas Indonesia.

Suratno, 2010. Pengaruh Strategi Kooperatif Jigsaw dan Reciprocal Teaching terhadap Keterampilan Metakognisi dan Hasil Belajar Kognitif Biologi Siswa SMA
Berkemampuan Atas dan Bawah. Disertasi tidak diterbitkan. Malang: Universitas Negeri Malang.

Tindangen, M. 2006. Implementasi Pembelajaran Kontekstual Peta Konsep Biologi SMP pada Siswa Berkemampuan Awal Berbeda di Kota Malang dan Pengaruhnya Terhadap Kemampuan Berpikir Tingkat Tinggi dan Hasil Belajar Kognitif. Disertasi tidak diterbitkan. Malang: PPs UM.

Warouw, Z.W.M. 2010. Pembelajaran Cooperative Script Metakognitif (CSM) yang Memberdayakan Keterampilan Metakognitif dan Hasil Belajar Siswa. Makalah disajikan dalam seminar Nasional Pendidikan Biologi. Jurusan Pendidikan Biologi. FKIP UNS, Surakarta, (Online), (http://jurnal.fkip.uns.ac.id), diakses 23 Agustus 2013. 